\title{
REVIEW
}

\section{Diversity in young shark habitats provides the potential for portfolio effects}

\author{
Peter M. Yates ${ }^{1, *}$, Michelle R. Heupel ${ }^{1,2}$, Andrew J. Tobin ${ }^{1}$, Colin A. Simpfendorfer ${ }^{1}$ \\ ${ }^{1}$ Centre for Sustainable Tropical Fisheries and Aquaculture \& School of Earth and Environmental Sciences, \\ James Cook University, Townsville, Queensland 4811, Australia \\ ${ }^{2}$ Australian Institute of Marine Science, PMB 3, Townsville, Queensland 4810, Australia
}

\begin{abstract}
The young (neonates, young-of-the-year and juveniles) of many shark species occupy a diverse range of habitats and areas. However, the contribution of individual nurseries or habitats to an adult population is difficult to quantify. In addition, little attention has been paid to the potential importance of 'non-nursery' young shark habitats to the long-term sustainability of shark populations. Portfolio theory predicts that contributions from a diverse range of young shark habitats may reduce variability in the overall production of adults, and maintain population resilience. This review examines case studies of portfolio effects in teleost fish and evaluates the relevance and potential implications of these processes for shark populations. Environmental heterogeneity in young shark habitats can result in locally adapted habitat-use patterns and life history traits. Therefore, young shark habitats may be differentially impacted by anthropogenic disturbance or environmental change, with different habitats performing well at different times. In addition, increased stability in production may be achieved when the effects of localised disturbance in one area are buffered by production in others. However, the behavioural and life history characteristics of some shark species may limit portfolio effects. These include the repeated use of a narrow range of habitats or areas for reproduction, and the production of relatively stable numbers of offspring. This description of the relevance of portfolio theory to shark populations highlights the importance of maintaining habitat diversity.
\end{abstract}

KEY WORDS: Shark · Nursery · Portfolio effect · Population sustainability · Elasmobranch • Fisheries Resale or republication not permitted without written consent of the publishe

\section{INTRODUCTION}

Sharks are high-order predators and a crucial component of marine ecosystems. However, the harvest of sharks has considerable social and economic significance around the world, and therefore many species are heavily utilised in fisheries. The life history characteristics of some shark species increase their vulnerability to exploitation, and estimated population declines in some species (Graham et al. 2001, Dudley \& Simpfendorfer 2006) have fuelled global interest in their conservation and management (Dulvy et al. 2008). Effective manage- ment of shark populations requires a detailed understanding of essential habitats and of how these are utilised by sharks. Accordingly, the location and functioning of shark nurseries has been a focus of recent research (Heupel et al. 2007, McCandless et al. 2007a, Heupel \& Simpfendorfer 2011). Appropriate management of inshore shark nurseries is particularly important because they can be utilised by numerous shark species (Simpfendorfer \& Milward 1993) and are increasingly susceptible to a range of anthropogenic impacts and environmental change (Chin et al. 2010, Knip et al. 2010, Koehn et al. 2011). 
The majority of marine nursery research has aimed to identify the most productive juvenile habitats in order to guide the focus of management and conservation efforts (Beck et al. 2001). Similarly, the designation of Essential Fish Habitat, Habitat Areas of Particular Concern, and Critical Habitat by the US National Marine Fisheries Service (NMFS) provides additional focus toward habitats that are of high importance to the long-term productivity of fish populations or that are particularly vulnerable to degradation. The juveniles of many marine species are spatially dispersed and utilise a wide range of habitats. For example, young-of-the-year blacktip sharks Carcharhinus limbatus and sandbar sharks $C$. plumbeus utilise numerous environmentally heterogeneous inshore waters along the Gulf of Mexico and east coast of the USA (Fig. 1). Beck et al. (2001) emphasise that marine nursery areas contribute disproportionately to adult stocks, and comprise only a subset of all habitats and regions where juveniles occur. However, comparison of multiple nursery areas in terms of their contributions to the maintenance of adult stocks is difficult to quantify. In addition, it is now well accepted that not all areas or habitats where

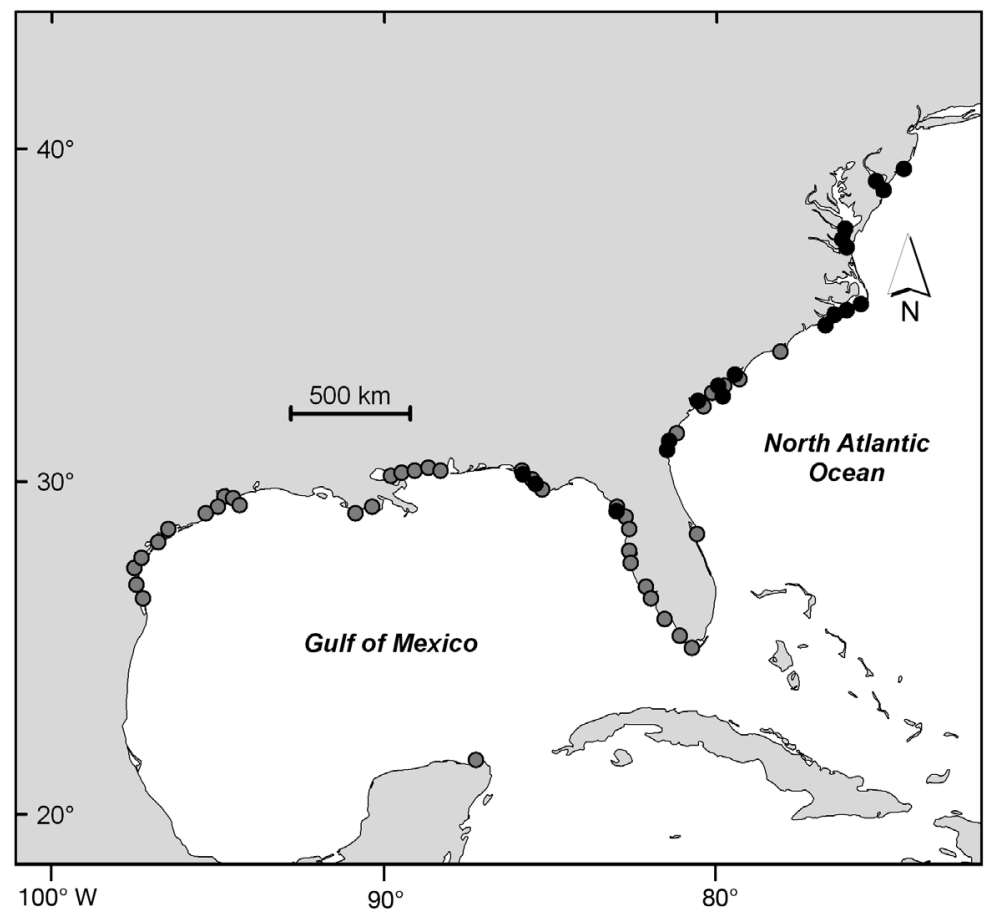

Fig. 1. Carcharhinus limbatus and C. plumbeus. Habitat diversity. Approximate areas utilised by neonate and/or young-of-the-year C. limbatus (O) and C. plumbeus (-) in the Gulf of Mexico and North Atlantic Ocean as indicated by capture locations in McCandless et al. (2002, 2007a). Note that a range of areas and habitats are utilised; however, not all of these will be classified as nurseries according to criteria in Heupel et al. (2007) young sharks are found necessarily function as shark nurseries, and non-nursery habitats may contribute significantly to the adult population in some situations (Dahlgren et al. 2006). For example, changes in environmental or anthropogenic factors may mean that currently productive young shark habitats fail, and other previously less-productive habitats may form a strong component of future production.

Heupel et al. (2007) provided 3 criteria for the identification of a shark nursery: (1) relatively high abundance of neonates or young juveniles, (2) site fidelity and (3) stable use across multiple years. These criteria provide a consistent approach to identifying the most important habitats for young sharks. For example, estuarine waters along the entire Texas coast were traditionally regarded as nursery areas for bull sharks Carcharhinus leucas based on the presence of young individuals; however only 2 estuaries function as nurseries for juvenile $C$. leucas according to the Heupel et al. (2007) criteria (and only 1 for young-ofthe-year sharks; Froeschke et al. 2010b). Few other shark (or ray) nurseries have been classified in this way, primarily due to a lack of data with adequate spatial and temporal scope (but see DeAngelis et al. 2008, Hussey et al. 2009, Curtis et al. 2011, Dale et al. 2011). The identification of shark nurseries using these criteria relies on the assumption that the locations of critical young shark habitats (i.e. those classified as nurseries) are stable through time. Similarly, temporal stability in abundance has been used as an indicator of nursery value in teleost fish (Fodrie \& Levin 2008, Colloca et al. 2009). However, the assumption of temporal stability in inshore nurseries is potentially problematic given the highly dynamic nature of inshore ecosystems (Robertson \& Duke 1987) and their susceptibility to anthropogenic alteration (Chin et al. 2010, Knip et al. 2010).

Locations utilised by young sharks can be classified as either 'nurseries' or 'other young shark habitats' (a concept originally proposed for teleost fish and invertebrates; Beck et al. 2001). These other habitats are utilised by young sharks, but are used inconsistently or by fewer individuals (Heupel et al. 2007). Further, reduced growth rates, survival and movement to adult populations can diminish the productivity of habitats and thus their suitability to be classified as nurseries 
(Beck et al. 2001). The contribution of other young shark habitats to the long-term sustainability of shark populations is poorly understood. For example, young school sharks Galeorhinus galeus used to be abundant in sheltered inshore systems of Tasmania and Victoria, Australia (Olsen 1954). More recently, Stevens \& West (1997) reported relatively low catches of young G. galeus in these inshore systems, and estimated that their contribution to total pup production was small $(<10 \%)$; and recruitment may now be maintained by production in other areas, such as exposed beaches, that were not traditionally regarded as pupping sites (Olsen 1954). This suggests that although exposed beaches may not have been significant nurseries prior to anthropogenic disturbance (that has resulted in substantially reduced abundance), they may contribute much of the current pup production of G. galeus.

Diversity within teleost fish stocks can reduce variability in production and contribute to long-term sustainability (Tilman 1996, Luck et al. 2003, Moore et al. 2010, Schindler et al. 2010). This reduction of variance is known as the portfolio effect (Figge 2004), and has been quantified within a sockeye salmon Oncorhynchus nerka stock in Bristol Bay, Alaska (Schindler et al. 2010). Portfolio effects in O. nerka may also be occurring in Bear Lake, Alaska (Boatright et al. 2004). These stock complexes are comprised of several hundred discrete breeding populations structured by morphological and life history traits including asynchronous migrations to different spawning habitats (Hilborn et al. 2003, Doctor et al. 2010, Greene et al. 2010). Differences in water temperature between spawning streams are an important driver of this stock structuring (Boatright et al. 2004). Complementary dynamics between these populations are thought to have allowed O. nerka stock complexes to sustain productivity despite large-scale environmental variations (Hilborn et al. 2003, Schindler et al. 2010). Further, the variability in commercial landings of $O$. nerka in Bristol Bay is 2.2 times lower than it would be in the presence of a more homogeneous population (i.e. the dominant age classes in the average stream population; Schindler et al. 2010). This variance-dampening resulted in 10 times fewer fishery closures than would have occurred in the presence of a more homogeneous population (Schindler et al. 2010). In contrast, extensive fish hatchery production and damming in the Snake River basin, Washington State, appears to have caused synchronisation of $>90 \%$ of spawning populations within the stock, raising serious conservation concerns and increasing the variability in annual $O$. nerka landings (Moore et al. 2010).

The definition of shark nurseries described by Heupel et al. (2007) can be used to identify the most heavily and consistently utilised young shark habitats (i.e. nurseries) and is an important tool for the management and conservation of sharks. The Heupel et al. (2007) definition is used to examine whether a specific area is nursery, whereas portfolio effects operate over broader spatial and temporal scales. Thus portfolio theory considers multiple habitats through time rather than focusing on a specific habitat or location. For example, this approach could be used to compare contributions of multiple nursery areas to the adult stock. In instances when discrete nurseries cannot be identified, the portfolio approach may be a useful means of examining the contributions of other young shark habitats. This approach can also be used to compare the importance of individual nursery areas (or nursery versus non-nursery areas) and examine variability in production over time.

The possibility of portfolio effects operating within shark stocks is unknown. However, the characteristics that allow portfolio effects to operate within Oncorhynchus nerka stocks may be shared by some shark species in their use of young shark habitats. This review outlines and discusses what is currently known about intraspecific diversity in habitat use by young sharks. The possibility of variance-dampening portfolio effects within young shark habitats will be explored, as well as the potential implications of these processes for shark populations and how they are managed.

\section{DIVERSITY IN YOUNG SHARK HABITATS}

Inshore environments typically support high biodiversity and productivity (Robertson \& Duke 1987, Blaber et al. 1989, Beck et al. 2001), and therefore provide important habitat for many shark species (Branstetter 1990, Simpfendorfer \& Milward 1993, White \& Potter 2004, Knip et al. 2010). The utilisation of inshore environments varies considerably between shark species; however, most are described by 2 general models. One model describes species that utilise inshore nurseries as juveniles before moving offshore to adult habitats (Springer 1967). Large coastal sharks such as Carcharhinus limbatus conform to this model (Springer 1967, Castro 1996). In contrast, the second model describes species that complete their entire life cycle within inshore envi- 
ronments (Knip et al. 2010), such as Australian sharpnose sharks Rhizoprionodon taylori. A portion of the species represented by this model exhibit site fidelity within restricted inshore sites (Sims et al. 2001), and others traverse larger areas (Parsons \& Hoffmayer 2005, Carlson et al. 2008). Because of this diversity in inshore habitat use through ontogeny, anthropogenic impacts occurring within inshore habitats will affect different species in different ways. Sharks that complete their life cycle within inshore environments may be affected to a greater extent by unfavourable conditions because all age classes may be affected concurrently (Knip et al. 2010).

Owing to the diverse range of shark life histories, not all species utilise discrete nursery areas (Heupel et al. 2007), and those that do may benefit from them in different ways (Heithaus 2007). Small sharks are both predators and prey, and how a species balances the trade-off between predator avoidance and energy uptake can often be related to its life history (Branstetter 1990), as well as competitive interactions between individuals (Brown 1999, Heithaus 2004, 2007). It is widely assumed that nursery areas benefit young sharks by providing ample food and protection from predators (Springer 1967, Branstetter 1990, Ryer et al. 2010, Heupel \& Simpfendorfer 2011). There are some notable exceptions to this longstanding assumption, including indications that these 2 factors may be mutually exclusive in at least some cases (Heithaus 2007, Heupel et al. 2007). For example, resource limitation occurs in some protected nurseries (Lowe 2002, Bush 2003, Hoffmayer et al. 2006), and movements of young sharks are driven by predator avoidance and not prey distribution in other nurseries (Heupel \& Hueter 2002, Heupel \& Simpfendorfer 2005). Some energetically productive nurseries offer abundant food for small sharks, but may be frequented by large predatory sharks for the same reason (Branstetter 1990, Heithaus 2007), in some cases necessitating fine-scale spatial partitioning (Kinney 2011). In general, large-bodied and slow-growing shark species may receive greater benefit from predator avoidance than small-bodied, fast-growing species (Branstetter 1990). Accordingly, the former typically utilise more protected nurseries. There remains scarce information on how life history factors, as well as abiotic environmental factors, influence the selection and use of nurseries by young sharks (Heithaus 2007).

In addition to interspecific variation in habitat use based on life history patterns, space utilisation within young shark habitats varies between species. Juvenile pigeye sharks Carcharhinus amboinensis have been shown to occupy relatively small home ranges in coastal waters (Knip et al. 2011b). In contrast, $C$. plumbeus have been reported to use larger areas, although usually remaining within the confines of a single estuary or embayment (Grubbs et al. 2007, Conrath \& Musick 2010). How young sharks utilise space has important implications for their resilience to localised impacts occurring within their ranges, with some species having a greater ability to move away from unfavourable conditions than others. For example, juvenile lemon sharks Negaprion brevirostris are strongly site-attached to mangrove and seagrass habitats within isolated nursery lagoons. In one such lagoon, Jennings et al. (2008) reported a $23.5 \%$ reduction in juvenile survival in the year following localised dredging activities and associated declines in seagrass coverage. Negligible migration between $N$. brevirostris nurseries appears to be the norm (Gruber et al. 1988, 2001, Morrissey \& Gruber 1993a, 1993b, DiBattista et al. 2007, Jennings et al. 2008), and this strong site attachment may have precluded movement away from the degraded habitat. In contrast, $C$. leucas move out of their usual young shark habitats and into adjacent embayments in response to low salinity events (Simpfendorfer et al. 2005, Heupel \& Simpfendorfer 2008). Portfolio theory suggests that resilience might also be improved when conspecific young sharks are distributed among multiple young shark habitats along environmentally heterogeneous coastal stretches.

Environmental and habitat heterogeneity has been shown to influence habitat use within and between young shark habitats as well as through time. For example, how young sharks optimise predator avoidance and foraging success may be facilitated and influenced by heterogeneity in environmental factors (Kinney 2011). High turbidity is thought to provide protection from predation for juvenile estuarine fish (Blaber \& Blaber 1980). Similarly, multiple species of young sharks in Cleveland Bay, Australia, were more abundant in shallow $(<5 \mathrm{~m})$, turbid habitat whereas adults usually inhabited deeper waters further from shore (Kinney 2011, Knip et al. 2011b). In contrast, juvenile spot-tail sharks Carcharhinus sorrah showed a preference for deeper, less turbid habitat, which may represent a trade-off against predator avoidance in order to reduce resource competition with other juvenile sharks (Kinney 2011). Similarly, juvenile slit-eye sharks Loxodon macrorhinus in Hervey Bay, Australia showed a preference for shallow areas with lower turbidity, which may represent predator avoidance or resource partitioning in order to optimise foraging success (Gutteridge et al. 2011). In Florida, juvenile $C$. 
leucas displayed spatial segregation by body size, thus partitioning available food resources and reducing competition between size classes (Simpfendorfer et al. 2005). This partitioning by C. leucas appears to be driven by temperature and salinity gradients along with varying preferences for these parameters between size classes (Simpfendorfer et al. 2005, Heupel \& Simpfendorfer 2008). These findings highlight the importance of environmental variables as determinants of habitat use by young sharks and the imperative for improved understanding of how anthropogenic disturbances, habitat restoration and climatic change will affect shark populations.

Over large spatial scales, intraspecific differences in habitat use may be driven by varying environmental conditions associated with changes in latitude. For example, inshore systems in the northwestern Atlantic are some of the most seasonally dynamic aquatic habitats in the world, where temperatures range up to $28^{\circ} \mathrm{C}$ between summer and winter (Coutant 1985, Grubbs et al. 2007). Accordingly, the majority of teleost and shark fauna in these habitats are seasonal migrants (Musick et al. 1985, Grubbs et al. 2007, Heupel 2007). In contrast, young shark habitats in tropical and subtropical regions are utilised year-round, although species composition may change seasonally (see Simpfendorfer \& Milward 1993). The implications of seasonal and year-round use of young shark habitats for their inhabitants are unclear. Seasonal migrations, and thus large expenditures of energy, are typically not required in tropical young shark habitats (Simpfendorfer \& Milward 1993). This may provide more energy for growth in tropical areas, as well as mitigate the presumed increase in predation risk on young sharks during seasonal migrations (Branstetter 1990). Conversely, sharks in tropical regions may be challenged in other ways. For example, inter-annual variations in water temperature are generally smaller in tropical marine environments than those in temperate environments. As a result, tropical fish species may be less resilient to elevated temperatures and climate warming (Munday et al. 2008), a pattern that is also reported in terrestrial ecosystems (Williams et al. 2003, Deutsch et al. 2008). Tropical young shark habitats can also undergo significant seasonal fluctuations in other environmental variables such as rainfall (Knip et al. 2011a) and prey availability (Staples 1979, Simpfendorfer \& Milward 1993), and these fluctuations represent potential stressors for tropical shark species. These different challenges suggest that the effects of environmental changes might vary within shark stocks that span climatic transition zones.
Intraspecific differences in habitat use over large spatial scales may also be driven by differences in available habitat types. Differences in biotic and abiotic characteristics may require sharks to adopt different strategies in different areas (see Knip et al. 2010 for review). This suggests that habitat plays a crucial role in driving how sharks use space and that populations will alter their habitat-use patterns as required. For example, juvenile Carcharhinus plumbeus inhabit discrete areas within inshore systems of the northwest Atlantic (Conrath \& Musick 2010). However, in the eastern Indian Ocean, juvenile $C$. plumbeus utilise larger areas further offshore (McAuley et al. 2007). These 2 populations of the same species use different habitats, which suggests that inshore habitats are more beneficial to juveniles off the coast of North America, while offshore habitat must provide greater benefits to juveniles in the eastern Indian Ocean. Therefore, it is possible that differences in available habitats along environmentally heterogeneous coastal stretches may influence intraspecific differences in nursery use over smaller spatial scales.

Sharks are known to exhibit intraspecific differences in habitat use over smaller spatial scales than those described above (for example see Taylor et al. 2011), and the unique and dynamic nature of inshore areas suggests that proximate inshore systems should not be treated interchangeably in terms of the services they provide young sharks (Knip et al. 2010). For example, habitat utilisation by young Carcharhinus plumbeus varied between 2 large adjacent embayments in the northwest Atlantic Ocean. In Delaware Bay, young-of-the-year sharks were most abundant in shallow, slow current areas and both young-of-the-year and juveniles avoided deep channels with faster currents (McCandless et al. 2007b). In contrast, juvenile Carcharhinus plumbeus in Chesapeake Bay were more abundant in deeper channels (>5.5 m), which were protected from strong currents (Grubbs \& Musick 2007). One explanation for this variation between the 2 embayments may be that young Carcharhinus plumbeus prefer areas with slower currents. Alternatively, predation risk from sand tiger sharks Carcharias taurus present in deep channels within Delaware Bay, but absent in Chesapeake Bay, may also explain the observed differences in habitat use between these sites (McCandless et al. 2007b). Further assessment of Carcharhinus plumbeus habitat use between Chesapeake and Delaware Bays may facilitate a greater understanding of the most important environmental factors for young sharks in this region, and may help managers 
to preserve those attributes, as well as to rehabilitate other areas where anthropogenic impacts have occurred (Heithaus 2007). In addition, variation in habitat use between young shark habitats might allow for portfolio effects. Since Carcharhinus plumbeus demonstrate different patterns of habitat use between areas, the effects of environmental change may not affect this species in these 2 areas equally. Therefore, this kind of combined occurrence of multiple heterogeneous young shark habitats potentially contributes to population resilience and sustainability.

\section{POTENTIAL DRIVERS OF PORTFOLIO EFFECTS IN SHARKS}

In Oncorhynchus nerka, precise natal philopatry for spawning, coupled with the ability to thrive in a wide range of environmental conditions, facilitates reproductive isolation and local adaptation to natal streams and thus portfolio effects (Taylor 1991, Hilborn et al. 2003, Doctor et al. 2010, Schindler et al. 2010). Sharks are also reported to demonstrate reproductive philopatry (Hueter et al. 2004), as well as local adaptations and life history diversity between different regions (Harry et al. 2011), albeit at a much larger geographic scale than in O. nerka. For example, in some regions, male scalloped hammerhead sharks Sphyrna lewini disperse to occupy offshore environments as adults (Hazin et al. 2001, De Bruyn et al. 2005), whereas males in other regions remain in inshore areas (Harry et al. 2011). These habitat-use patterns are also associated with differences in body size and longevity, and may have resulted from the influence of regional habitat differences in a tradeoff between reproductive success and reproductive opportunity (Harry et al. 2011). Taken together, results from genetic, vertebral microchemistry and life history studies indicate stock structuring within single genetic stocks of $S$. lewini that extend $\sim 2000 \mathrm{~km}$ along eastern Australia (Welch et al. 2011). This range crosses a transition between tropical inshore lagoons to subtropical rocky shores (Ovenden et al. 2011, Welch et al. 2011). Stock structuring in $S$. lewini is facilitated by site fidelity, although limited regional migration provides connectivity between sub-stocks and may allow for replenishment of depleted populations (Welch et al. 2011). These findings suggest that like O. nerka, some shark populations cover a range of environmental and habitat conditions, and can be structured according to local adaptations to their environment. Spatially distinct components of the stock may therefore perform differently, allowing for portfolio effects to operate over large spatial scales.

Over smaller spatial scales (e.g. $\sim 500 \quad \mathrm{~km}$; Froeschke et al. 2010a), the young of some shark species are distributed across environmentally heterogeneous coastal stretches (McCandless et al. 2007a, Ovenden et al. 2011, Welch et al. 2011), and this habitat diversity may also facilitate portfolio effects. Variations in depth (Grubbs \& Musick 2007), turbidity (Ortega et al. 2009, Knip et al. 2011b), vegetation and substratum type (Morrissey \& Gruber 1993b, White \& Potter 2004), salinity (Simpfendorfer et al. 2005, Abel et al. 2007, Ubeda et al. 2009, Knip et al. 2011a), dissolved oxygen (Heithaus et al. 2009, Ortega et al. 2009) and temperature (Froeschke et al. 2010a, Espinoza et al. 2011) have been found to influence habitat use by young sharks. In some teleost fish, environmental heterogeneity appears to drive localised adaptation and thus differences in behaviour (Mariani et al. 2011) and species richness (Sheaves \& Johnston 2009) between proximate estuaries. In addition, some seagrass- and mangroveassociated teleosts exhibit varying levels of flexibility in habitat use through time and between nearby locations (Kimirei et al. 2011). Indeed, high interannual environmental variability within inshore waters is known to produce starkly contrasting fishery productivities in some teleosts (Balston 2009). However, the degree to which heterogeneity in environmental factors drives intraspecific diversity in young shark habitat use within a region is largely unknown, as are the effects of environmental changes.

Utilisation of multiple heterogeneous habitats improves the adaptability of a species to anthropogenic disturbance and environmental change where these effects unevenly impact throughout a species distribution (Secor et al. 2009). This act of 'bet-hedging' is an example of the portfolio effect. Diversity in juvenile shark habitats may drive portfolio effects whereby the effects of unfavourable conditions in one place or habitat type are buffered by production in others. Low-salinity events (Knip et al. 2011a), toxic algae blooms (Nam et al. 2010), pollution (Gelsleichter et al. 2005), coastal development (Jennings et al. 2008), resource limitation (Lowe 2002) and localised fisheries (Stevens \& West 1997) are examples of events that can create unfavourable conditions for young sharks. Over longer temporal scales, different populations can perform well at different times, and young shark habitats that are minor producers during one environmental (e.g. climatic) 
regime can be major producers in others, as is the case for Oncorhynchus nerka (Hilborn et al. 2003).

Long-term fishery-independent catch data along the Texas coast indicate that the productivity of young Carcharhinus leucas within 8 embayments was not static through time (Froeschke et al. 2010b). Rather, abundance fluctuated within these sites, and it is their combined occurrence that might allow for complementary dynamics in productivity between bay systems (Fig. 2). Of the 8 sites sampled, only Matagorda Bay satisfied all 3 criteria for classification as a nursery (according to Heupel et al. 2007) for young-of-the-year C. leucas (Froeschke et al. 2010b). However, it is important to consider the contributions of other young-ofthe-year habitats, because cumulatively they reduced Texas' total variance in the abundance of young-of-the-year C. leucas (Table 1, Fig. 2). This finding has population-level implications, because abundance data of young sharks (e.g. catch per unit effort) can be used as a proxy for young shark habitat productivity (Garofalo et al. 2011). Therefore, this collection of embayments may act to stabilise total recruitment of adult $C$. leucas in this
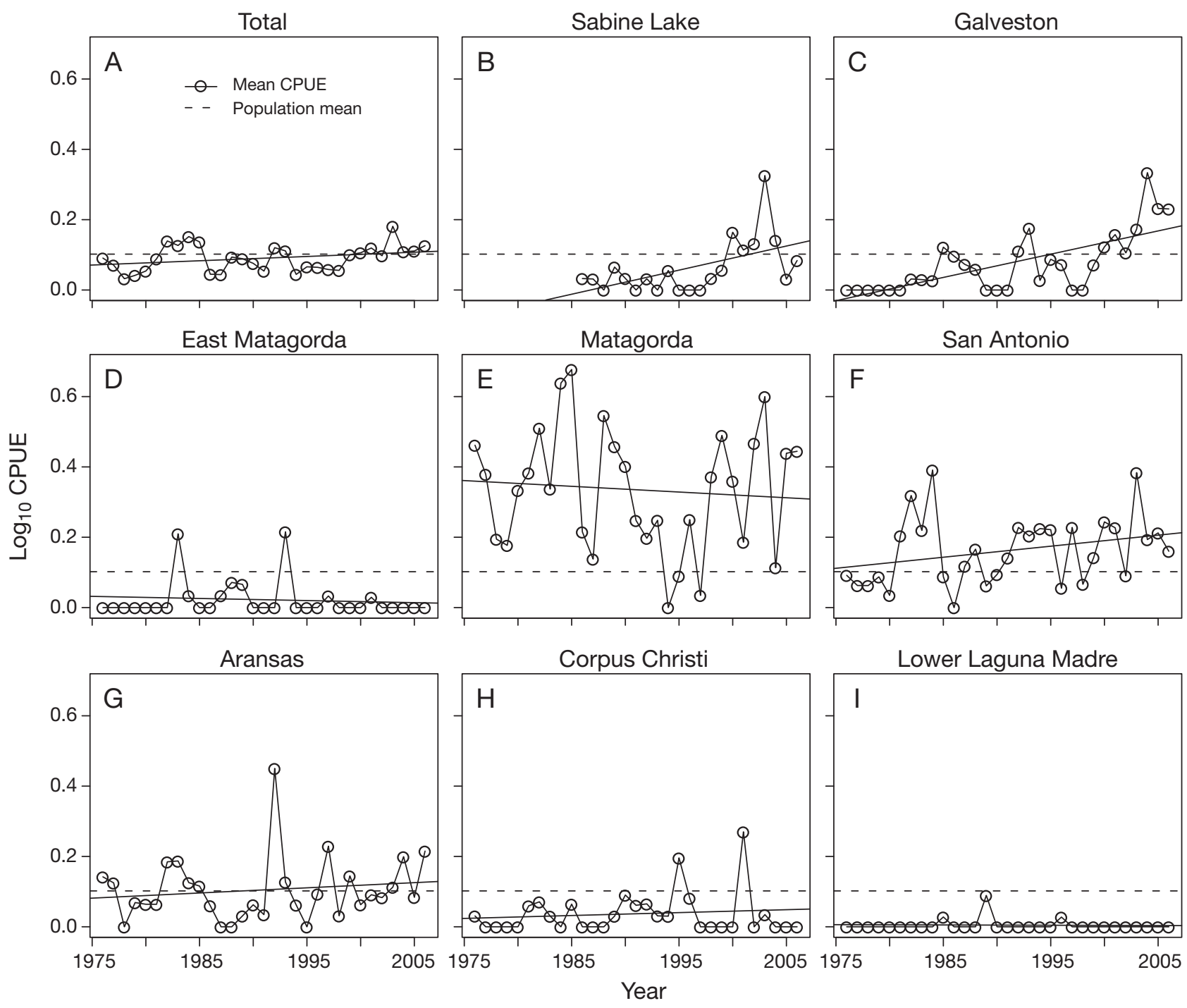

Fig. 2. Carcharhinus leucas. Young-of-the-year abundance in 8 estuarine embayments along the Texas coast (A: whole region; $\mathrm{B}$ to I: locations corresponding to Table 1). Inter-annual variation in $\log _{10}$ catch per unit effort (CPUE; sharks $\mathrm{h}^{-1}$ ) within each site is evident (B to $\mathrm{I}_{i} \mathrm{O}=$ annual mean). Abundance in some sites fluctuates above and below the population mean (broken line), and therefore they vary in their suitability to meet the first criterion for a shark nursery (i.e. abundance in the area $>$ mean abundance over all areas; Heupel et al. 2007). Portfolio effects may operate across these young-of-the-year habitats because variability in mean CPUE for the whole region (A) is less than the variability in individual sites. (From Froeschke et al. 2010b. With permission) 
Table 1. Carcharhinus leucas. Mean $\log _{10}$ catch per unit effort (CPUE; sharks $\mathrm{h}^{-1}$ ) and variability in $\log _{10}$ CPUE of young-of-the-year bull sharks within 8 Texas embayments between 1976 and 2006 (J. T. Froeschke pers. comm.). Note that variability in abundance across the region (Total) is less than variability in abundance in individual embayments, suggesting that portfolio effects may occur across this region

\begin{tabular}{|lccc|}
\hline \multirow{2}{*}{ Location } & \multicolumn{3}{c|}{$\log _{10}$ CPUE } \\
\cline { 2 - 4 } & Mean & SD & CV \\
\hline Sabine Lake & 0.063 & 0.078 & 1.236 \\
Galveston Bay & 0.075 & 0.086 & 1.136 \\
East Matagorda Bay & 0.005 & 0.017 & 3.674 \\
Matagorda Bay & 0.335 & 0.176 & 0.526 \\
San Antonio Bay & 0.162 & 0.097 & 0.601 \\
Aransas Bay & 0.105 & 0.091 & 0.864 \\
Corpus Christi Bay & 0.037 & 0.061 & 1.639 \\
Lower Laguna Madre & 0.022 & 0.054 & 2.432 \\
Total & 0.102 & 0.042 & 0.411 \\
\hline
\end{tabular}

region and hence annual yield of the fisheries in which they are captured.

Philopatry is an important consideration in the discussion of the potential for portfolio effects in young shark habitats. The combination of precise natal philopatry and the ability to thrive in a range of environmental conditions contributes to portfolio effects in Oncorhynchus nerka because it allows for reproductive isolation, localised adaptations to a large number of natal streams, and asynchronous spawning migrations. Portfolio effects operate in O. nerka because environmental changes do not affect production across all natal streams equally (Schindler et al. 2010). Sharks demonstrate various forms of philopatry, including juveniles returning to specific summer habitats (Castro 1996, McCandless et al. 2007b, Conrath \& Musick 2010), and adult females returning to broad mating and pupping regions (Feldheim et al. 2004, Hueter et al. 2004, Keeney et al. 2005, DiBattista et al. 2008). However, the spatial scale and precision of philopatry in sharks remains poorly understood, as do the implications of philopatry for portfolio effects.

If environmental conditions remain stable, philopatry may increase the likelihood of offspring experiencing suitable environmental conditions, therefore enhancing survival. However, philopatry may reduce adaptability to anthropogenic impacts or environmental change, whereby individuals might return to the same place to reproduce even if conditions become unfavourable (Secor et al. 2009), thus compromising offspring survival and fitness and creating population-level problems. In addition, recovery of philopatric shark species from localised impacts (such as overfishing) will be slow compared to lessphilopatric species because they will receive less replenishment from production in other areas (Hueter et al. 2004, DiBattista et al. 2008). Therefore, mating- or pupping-site fidelity in adults might limit portfolio effects, especially if a species is philopatric to a narrow range of habitats or geographic locations. Similarly, many teleost species repeatedly aggregate at specific locations to spawn, which drastically increases their susceptibility to overfishing and localised extirpation (Sala et al. 2001). The risks associated with philopatry may be mitigated if sharks utilise multiple environmentally heterogeneous young shark habitats (Secor et al. 2009).

Straying of young sharks away from where they were born might also overcome some of the potential risks of reproductive philopatry. It has generally been assumed that young shark habitat location is governed by where parturition occurs whereby young sharks remain in the vicinity of where they were born, with the ability to only select microhabitats within these areas (Springer 1967, Heithaus 2007). However, there are numerous examples of young sharks - even in species with philopatric young - moving away from where they were born, suggesting that birth location may be less influential in determining where young shark habitats occur than traditionally thought (Castro 1993, Heupel et al. 2004, Aubrey \& Snelson 2007, McCandless et al. 2007b, Farrugia et al. 2011). Movement of young sharks around or away from where they were born might influence the amount of diversity in youngshark habitat use within a species (Branstetter 1990), as young sharks may spread themselves across a mosaic of habitats. In addition, movements of young sharks away from where they were born in response to localised impacts might facilitate portfolio effects by boosting production in the habitats to which they move.

Most shark species possess life history traits that are different to those of Oncorhynchus nerka and other teleost fish, and it is important to consider whether these differences might limit the potential for, or the magnitude of the benefits obtained from, portfolio effects in young shark habitats. K-selected life history characteristics observed in sharks allow for the production of relatively stable numbers of large-bodied and actively swimming offspring. In contrast, most teleost fish produce vast numbers of smaller-bodied offspring that are highly dependent on environmental variables (Cole \& McGlade 1998, Balston 2009). Although environmental and habitat variables have been shown to influence neonate 
shark survival and fitness (Lowe 2002, Bush 2003, Hoffmayer et al. 2006, Jennings et al. 2008, Nam et al. 2010), they presumably are less impacted by their environment than are larval fish. Therefore, the benefits obtained from portfolio effects may be limited in young shark habitats because temporal stability in production could be achieved through their life histories rather than portfolio effects between numerous fluctuating habitats.

\section{IMPLICATIONS FOR MANAGEMENT AND CONSERVATION}

This review has demonstrated the potential for portfolio effects to operate within young shark habitats as well as the factors that may promote or limit the occurrence and magnitude of portfolio effects. However, further research is required to confirm whether portfolio effects occur in these habitats, and if they should be considered in management decisions. Portfolio effects were quantified in Alaskan Oncorhynchus nerka by comparing the variability in annual fish landings of the stock complex with the variability in fish landings in individual rivers (Schindler et al. 2010). A similar method could be used to quantify the occurrence and strength of portfolio effects in young shark habitats, whereby the variability (e.g. coefficient of variation [CV]) in young shark abundance across a range of habitats is compared to the variability in abundance within individual habitats of the same region. Abundance surveys across a range of young shark habitats can be used to test the prediction that although abundance in individual habitats is highly variable through time, the overall abundance and thus recruitment across the population or region is relatively stable (e.g. Froeschke et al. 2010b). More recently, Carlson \& Satterthwaite (2011) discuss some of the limitations of using $\mathrm{CV}$ as a metric of stability in teleost fish, and promote the use of additional metrics such as correlations in productivity among stock components, an idea also explored by Schindler et al. (2010).

Identification of whether portfolio effects operate in young shark habitats is important because these processes are likely to provide population-level benefits for sharks and may be a critical consideration for shark management and conservation. The current method for identifying shark nurseries (Heupel et al. 2007) assumes that the location of the most important habitats (i.e. shark nurseries) is stable through time. However, sharks generally occur in low densities and with high temporal and spatial variability in abun- dance (Froeschke et al. 2010a). Indeed, significant temporal variability in Carcharhinus leucas abundance within the most heavily utilised young shark habitats was recorded in the Gulf of Mexico, including periods when shark abundance in these areas fell below the population mean, and therefore violated one of the criteria for classification as a nursery (our Fig. 2; Froeschke et al. 2010b). In the presence of portfolio effects, these fluctuations should not be as significant at the population level. Therefore, the importance of young shark habitats may be a function of their individual contributions to adult recruitment, as well as their combined occurrence and relationship with each other, an idea originally proposed for teleost fish (Meynecke et al. 2007). Accordingly, the conservation of a geographically diverse range of juvenile habitats has been identified as an important factor in the recovery of the endangered smalltooth sawfish Pristis pectinata in the USA by minimising the risk of stochastic local-scale disasters including hurricanes and fish kills (NMFS 2009). Indeed, toxic dinoflagellate algae blooms (red tides) have caused mass fish mortality within inshore embayments within $P$. pectinata's range (Flaherty \& Landsberg 2011), and the population-level impacts of these events will be partially mitigated by production of juveniles in other less-affected areas. In the absence of such extreme events, portfolio effects across multiple areas may also stabilise the population-level production of juvenile $P$. pectinata.

Portfolio theory provides the ability to consider contributions of a range of young shark habitats, including those that currently appear relatively unproductive or are not classified as shark nurseries according to Heupel et al. (2007). Portfolio theory can be used to explore whether habitats that are not classified as Essential Fish Habitat, Habitat Areas of Particular Concern, or Critical Habitat at one point in time may contribute to the sustainability of shark stocks over the long term. For example, young-ofthe-year Carcharhinus leucas abundance in Galveston Bay and Sabine Lake, Texas has increased over the last decade to above the population mean, and therefore these sites may now qualify as nurseries (our Fig. 2; Froeschke et al. 2010b). This demonstrates that nursery use and habitat quality may not be stable through time, and these changes may influence the production of young sharks across a range of areas (Froeschke et al. 2010b). Additional threats such as fishing pressure will continue to alter the productivity of these habitats. Non-uniform harvest of Alaskan Oncorhynchus nerka's natal streams (e.g. through temporally selective fishing) threatens to 
reduce their phenotypic and genetic diversity (Doctor et al. 2010). Theory predicts that this homogenisation erodes portfolio performance, thus increasing vulnerability to environmental change and the likelihood of synchronous population crashes (Heino et al. 1997, Engen et al. 2002, Moore et al. 2010). Similarly, spatially selective fishing in young shark habitats could reduce their phenotypic and genetic diversity, and may therefore compromise the long-term sustainability of shark fisheries and the conservation of endangered shark populations. Further, shark populations with weak or no portfolio effects may be more susceptible to depletion and therefore should be managed more conservatively.

\section{CONCLUSIONS}

Criteria for classifying young shark habitats are essential for identifying the most important habitats for juveniles, and allow fisheries managers and scientists to optimise the effectiveness of management, conservation and research efforts. However, the young of many shark species are spatially dispersed and utilise a wide range of habitats, some of which do not currently meet the criteria for classification as shark nurseries. The contribution of these various habitats to the long-term sustainability of shark populations remains poorly understood. In response to environmental change, areas of high shark density may change over time, and less important habitats under one set of conditions may be more important during others. Portfolio theory predicts that contributions from a wide range of young shark habitats should stabilise the population-level recruitment of adults.

\section{LITERATURE CITED}

Abel DC, Young RF, Garwood JA, Travaline MJ, Yednock BK (2007) Survey of the shark fauna in two South Carolina estuaries and the impact of salinity structure. Am Fish Soc Symp 50:109-124

Aubrey CW, Snelson FF (2007) Early life history of the spinner shark in a Florida nursery. Am Fish Soc Symp 50: 175-189

Balston J (2009) Short-term climate variability and the commercial barramundi (Lates calcarifer) fishery of northeast Queensland, Australia. Mar Freshw Res 60:912-923

> Beck MW, Heck KL, Able KW, Childers DL (2001) The identification, conservation and management of estuarine and marine nurseries for fish and invertebrates. Bioscience 51:633-641

Blaber SJM, Blaber TG (1980) Factors affecting the distribution of juvenile estuarine and inshore fish. J Fish Biol 17: 143-162

Blaber SJM, Brewer DT, Salini JP (1989) Species composi- tion and biomasses of fishes in different habitats of a tropical northern Australian estuary: their occurrence in the adjoining sea and estuarine dependence. Estuar Coast Shelf Sci 29:509-531

> Boatright C, Quinn T, Hilborn R (2004) Timing of adult migration and stock structure for sockeye salmon in Bear Lake, Alaska. Trans Am Fish Soc 133:911-921

Branstetter S (1990) Early life-history implications of selected Carcharhinoid and Lamnoid sharks of the northwest Atlantic. NOAA Tech Rep NMFS 90:17-28

Brown JS (1999) Vigilance, patch use and habitat selection: foraging under predation risk. Evol Ecol Res 1:49-71

Bush A (2003) Diet and diel feeding periodicity of juvenile scalloped hammerhead sharks, Sphyrna lewini, in Kā ne'ohe Bay, Ō'ahu, Hawai'i. Environ Biol Fishes 67:1-11

Carlson SM, Satterthwaite WH (2011) Weakened portfolio effect in a collapsed salmon population complex. Can J Fish Aquat Sci 68:1579-1589

Carlson JK, Heupel MR, Bethea DM, Hollensead LD (2008) Coastal habitat use and residency of juvenile Atlantic sharpnose sharks (Rhizoprionodon terraenovae). Estuar Coasts 31:931-940

> Castro JI (1993) The shark nursery of Bulls Bay, South Carolina, with a review of the shark nurseries of the southeastern coast of the United States. Environ Biol Fishes 38: $37-48$

Castro JI (1996) Biology of the blacktip shark, Carcharhinus limbatus, off the southeastern United States. Bull Mar Sci 59:508-522

Chin A, Kyne PM, Walker TI, McAuley RB (2010) An integrated risk assessment for climate change: analysing the vulnerability of sharks and rays on Australia's Great Barrier Reef. Glob Change Biol 16:1936-1953

Cole J, McGlade J (1998) Clupeoid population variability, the environment and satellite imagery in coastal upwelling systems. Rev Fish Biol Fish 8:445-471

Colloca F, Bartolino V, Lasinio GJ, Maiorano L, Sartor P, Ardizzone G (2009) Identifying fish nurseries using density and persistence measures. Mar Ecol Prog Ser 381: 287-296

Conrath CL, Musick JA (2010) Residency, space use and movement patterns of juvenile sandbar sharks (Carcharhinus plumbeus) within a Virginia summer nursery area. Mar Freshw Res 61:223-235

> Coutant CC (1985) Striped bass, temperature, and dissolved oxygen: a speculative hypothesis for environmental risk. Trans Am Fish Soc 114:31-61

> Curtis TH, Adams DH, Burgess GH (2011) Seasonal distribution and habitat associations of bull sharks in the Indian River Lagoon, Florida: a 30-year synthesis. Trans Am Fish Soc 140:1213-1226

Dahlgren CP, Kellison GT, Adams AJ, Gillanders BM and others (2006) Marine nurseries and effective juvenile habitats: concepts and applications. Mar Ecol Prog Ser 312:291-295

> Dale JJ, Wallsgrove NJ, Popp BN, Holland KN (2011) Nursery habitat use and foraging ecology of the brown stingray Dasyatis lata determined from stomach contents, bulk and amino acid stable isotopes. Mar Ecol Prog Ser 433:221-236

> DeAngelis BM, McCandless CT, Kohler NE, Recksiek CW, Skomal GB (2008) First characterization of shark nursery habitat in the United States Virgin Islands: evidence of habitat partitioning by two shark species. Mar Ecol Prog Ser 358:257-271 
De Bruyn P, Dudley SFJ, Cliff G, Smale MJ (2005) Sharks caught in the protective gill nets off KwaZulu-Natal, South Africa. 11. The scalloped hammerhead shark Sphyrna lewini (Griffith and Smith). Afr J Mar Sci 27: 517-528

Deutsch CA, Tewksbury JJ, Huey RB, Sheldon KS, Ghalambor CK, Haak DC, Martin PR (2008) Impacts of climate warming on terrestrial ectotherms across latitude. Proc Natl Acad Sci USA 105:6668-6672

> DiBattista JD, Feldheim KA, Gruber SH, Hendry AP (2007) When bigger is not better: selection against large size, high condition and fast growth in juvenile lemon sharks. J Evol Biol 20:201-212

> DiBattista JD, Feldheim KA, Thibert-Plante X, Gruber SH, Hendry AP (2008) A genetic assessment of polyandry and breeding-site fidelity in lemon sharks. Mol Ecol 17: 3337-3351

> Doctor KK, Hilborn R, Rowse M, Quinn T (2010) Spatial and temporal patterns of upriver migration by sockeye salmon populations in the Wood River system, Bristol Bay, Alaska. Trans Am Fish Soc 139:80-91

> Dudley SFJ, Simpfendorfer CA (2006) Population status of 14 shark species caught in the protective gillnets off KwaZulu-Natal beaches, South Africa, 1978-2003. Mar Freshw Res 57:225-240

> Dulvy NK, Baum JK, Clarke S, Compagno LJV and others (2008) You can swim but you can't hide: the global status and conservation of oceanic pelagic sharks and rays. Aquat Conserv Mar Freshw Ecosyst 18:459-482

Engen S, Lande R, Sæther BE (2002) The spatial scale of population fluctuations and quasi-extinction risk. Am Nat 160:439-451

Espinoza M, Farrugia TJ, Lowe CG (2011) Habitat use, movements and site fidelity of the gray smooth-hound shark (Mustelus californicus Gill 1863) in a newly restored southern California estuary. J Exp Mar Biol Ecol 401:63-74

- Farrugia TJ, Espinoza M, Lowe CG (2011) Abundance, habitat use and movement patterns of the shovelnose guitarfish (Rhinobatos productus) in a restored southern California estuary. Mar Freshw Res 62:648-657

> Feldheim KA, Gruber SH, Ashley MV (2004) Reconstruction of parental microsatellite genotypes reveals female polyandry and philopatry in the lemon shark, Negaprion brevirostris. Evolution 58:2332-2342

Figge F (2004) Bio-folio: applying portfolio theory to biodiversity. Biodivers Conserv 13:827-849

Flaherty KE, Landsberg JH (2011) Effects of a persistent red tide (Karenia brevis) bloom on community structure and species-specific relative abundance of nekton in a Gulf of Mexico estuary. Estuar Coasts 34:417-439

> Fodrie FJ, Levin LA (2008) Linking juvenile habitat utilization to population dynamics of California halibut. Limnol Oceanogr 53:799-812

Froeschke J, Stunz GW, Wildhaber ML (2010a) Environmental influences on the occurrence of coastal sharks in estuarine waters. Mar Ecol Prog Ser 407:279-292

Froeschke J, Stunz GW, Sterba-Boatwright B, Wildhaber ML (2010b) An empirical test of the 'shark nursery area concept' in Texas bays using a long-term fisheries-independent data set. Aquat Biol 11:65-76

> Garofalo G, Fortibuoni T, Gristina M, Sinopoli M, Fiorentino F (2011) Persistence and co-occurrence of demersal nurseries in the Strait of Sicily (central Mediterranean): implications for fishery management. J Sea Res 66:29-38

Gelsleichter J, Manire CA, Szabo NJ, Cortés E, Carlson J,
Lombardi-Carlson L (2005) Organochlorine concentrations in bonnethead sharks (Sphyrna tiburo) from four Florida estuaries. Arch Environ Contam Toxicol 48: 474-483

> Graham KJ, Andrew NL, Hodgson KE (2001) Changes in relative abundance of sharks and rays on Australian South East Fishery trawl grounds after twenty years of fishing. Mar Freshw Res 52:549-561

> Greene CM, Hall JE, Guilbault KR, Quinn TP (2010) Improved viability of populations with diverse life-history portfolios. Biol Lett 6:382-386

Grubbs RD, Musick JA (2007) Spatial delineation of summer nursery areas for juvenile sandbar sharks in Chesapeake Bay, Virginia. Am Fish Soc Symp 50:63-86

Grubbs RD, Musick JA, Conrath CL, Romine JG (2007) Long-term movements, migration, and temporal delineation of a summer nursery for juvenile sandbar sharks in the Chesapeake Bay region. Am Fish Soc Symp 50: 87-108

Gruber SH, Nelson DR, Morrissey JF (1988) Patterns of activity and space utilization of lemon sharks, Negaprion brevirostris, in a shallow Bahamian lagoon. Bull Mar Sci 43:61-76

Gruber SH, De Marignac JRC, Hoenig JM (2001) Survival of juvenile lemon sharks at Bimini, Bahamas, estimated by mark-depletion experiments. Trans Am Fish Soc 130: 376-384

> Gutteridge AN, Bennett MB, Huveneers C, Tibbetts IR (2011) Assessing the overlap between the diet of a coastal shark and the surrounding prey communities in a sub-tropical embayment. J Fish Biol 78:1405-1422

- Harry AV, Macbeth WG, Gutteridge AN, Simpfendorfer CA (2011) The life histories of endangered hammerhead sharks (Carcharhiniformes, Sphyrnidae) from the east coast of Australia. J Fish Biol 78:2026-2051

> Hazin F, Fischer A, Broadhurst M (2001) Aspects of reproductive biology of the scalloped hammerhead shark, Sphyrna lewini, off northeastern Brazil. Environ Biol Fishes 61:151-159

> Heino M, Kaitala V, Ranta E, Lindström J (1997) Synchronous dynamics and rates of extinction in spatially structured populations. Proc R Soc Lond B 264:481-486

Heithaus MR (2004) Predator-prey interactions. In: Carrier JC, Musick JA, Heithaus MR (eds) Biology of the sharks and their relatives. CRC Press, London, p 487-521

Heithaus MR (2007) Nursery areas as essential shark habitats: a theoretical perspective. Am Fish Soc Symp 50: $3-13$

Heithaus MR, Delius BK, Wirsing AJ, Dunphy-Daly MM (2009) Physical factors influencing the distribution of a top predator in a subtropical oligotrophic estuary. Limnol Oceanogr 54:472-482

Heupel MR (2007) Exiting Terra Ceia Bay: an examination of cues stimulating migration from a summer nursery area. Am Fish Soc Symp 50:265-280

> Heupel MR, Hueter RE (2002) Importance of prey density in relation to the movement patterns of juvenile blacktip sharks (Carcharhinus limbatus) within a coastal nursery area. Mar Freshw Res 53:543-550

> Heupel MR, Simpfendorfer CA (2005) Quantitative analysis of aggregation behavior in juvenile blacktip sharks. Mar Biol 147:1239-1249

> Heupel MR, Simpfendorfer CA (2008) Movement and distribution of young bull sharks Carcharhinus leucas in a variable estuarine environment. Aquat Biol 1:277-289 
Heupel MR, Simpfendorfer CA (2011) Estuarine nursery areas provide a low-mortality environment for young bull sharks Carcharhinus leucas. Mar Ecol Prog Ser 433: 237-244 doi:10.3354/meps09191

> Heupel MR, Simpfendorfer CA, Hueter RE (2004) Estimation of shark home ranges using passive monitoring techniques. Environ Biol Fishes 71:135-142

- Heupel MR, Carlson JK, Simpfendorfer CA (2007) Shark nursery areas: concepts, definition, characterization and assumptions. Mar Ecol Prog Ser 337:287-297

Hilborn R, Quinn TP, Schindler DE, Rogers DE (2003) Biocomplexity and fisheries sustainability. Proc Natl Acad Sci USA 100:6564-6568

> Hoffmayer ER, Parsons GR, Horton J (2006) Seasonal and interannual variation in the energetic condition of adult male Atlantic sharpnose shark Rhizoprionodon terraenovae in the northern Gulf of Mexico. J Fish Biol 68: 645-653

Hueter RE, Heupel MR, Heist KJ, Kneey DB (2004) Evidence of philopatry in sharks and implications for the management of shark fisheries. J Northwest Atl Fish Sci 35: 239-247

> Hussey NE, McCarthy ID, Dudley SFJ, Mann BQ (2009) Nursery grounds, movement patterns and growth rates of dusky sharks, Carcharhinus obscurus: a long-term tag and release study in South African waters. Mar Freshw Res 60:571-583

> Jennings DE, Gruber SH, Franks BR, Kessel ST, Robertson AL (2008) Effects of large-scale anthropogenic development on juvenile lemon shark (Negaprion brevirostris) populations of Bimini, Bahamas. Environ Biol Fishes 83: 369-377

> Keeney DB, Heupel MR, Hueter RE, Heist EJ (2005) Microsatellite and mitochondrial DNA analyses of the genetic structure of blacktip shark (Carcharhinus limbatus) nurseries in the northwestern Atlantic, Gulf of Mexico, and Caribbean Sea. Mol Ecol 14:1911-1923

> Kimirei IA, Nagelkerken I, Griffioen B, Wagner C, Mgaya YD (2011) Ontogenetic habitat use by mangrove/seagrass-associated coral reef fishes shows flexibility in time and space. Estuar Coast Shelf Sci 92:47-58

Kinney MJ (2011) The communal nursery area paradigm revisited: niche overlap versus niche separation among juvenile shark species of Cleveland Bay. PhD thesis, James Cook University, Townsville

> Knip DM, Heupel MR, Simpfendorfer CA (2010) Sharks in nearshore environments: models, importance, and consequences. Mar Ecol Prog Ser 402:1-11

Knip DM, Heupel MR, Simpfendorfer CA, Tobin AJ, Moloney J (2011a) Wet-season effects on the distribution of juvenile pigeye sharks, Carcharhinus amboinensis, in tropical nearshore waters. Mar Freshw Res 62:658-667

- Knip KM, Heupel MR, Simpfendorfer CA, Tobin A, Moloney $\mathrm{J}$ (2011b) Ontogenetic shifts in movement and habitat use of juvenile pigeye sharks Carcharhinus amboinensis in a tropical nearshore region. Mar Ecol Prog Ser 425: 233-246

> Koehn JD, Hobday AJ, Pratchett MS, Gillanders BM (2011) Climate change and Australian marine and freshwater environments, fishes and fisheries: synthesis and options for adaptation. Mar Freshw Res 62:1148-1164

Lowe CG (2002) Bioenergetics of free-ranging juvenile scalloped hammerhead sharks (Sphyrna lewini) in Kāne'ohe Bay, Ō'ahu, HI. J Exp Mar Biol Ecol 278:141-156

> Luck GW, Daily GC, Ehrlich PR (2003) Population diversity and ecosystem services. Trends Ecol Evol 18:331-336

Mariani S, Boggan C, Balata D (2011) Food resource use in sympatric juvenile plaice and flounder in estuarine habitats. PSZNI: Mar Ecol 32(Suppl 1):96-101

- McAuley RB, Simpfendorfer CA, Hyndes GA, Lenanton RCJ (2007) Distribution and reproductive biology of the sandbar shark, Carcharhinus plumbeus (Nardo), in Western Australian waters. Mar Freshw Res 58:116-126

McCandless CT, Pratt HL, Kohler NE (2002) (eds) Shark nursery grounds of the Gulf of Mexico and the east coast waters of the United States: an overview. An internal report to NOAA's Highly Migratory Species Office. NOAA Fisheries, Narragansett, RI

McCandless CT, Kohler NE, Pratt HL (2007a) (eds) Shark nursery grounds of the Gulf of Mexico and the east coast waters of the United States. Am Fish Soc Symp Vol 50. American Fisheries Society, Bethesda, MD

McCandless CT, Pratt HL, Kohler NE, Merson RR, Recksiek CW (2007b) Distribution, localized abundance, movements, and migrations of juvenile sandbar sharks tagged in Delaware Bay. Am Fish Soc Symp 50:45-62

Meynecke J, Lee SY, Duke N, Warnken J (2007) Relationships between estuarine habitats and coastal fisheries in Queensland, Australia. Bull Mar Sci 2007:773-793

Moore JW, McClure M, Rogers LA, Schindler DE (2010) Synchronization and portfolio performance of threatened salmon. Conserv Lett 3:340-348

Morrissey JF, Gruber SH (1993a) Home range of juvenile lemon sharks, Negaprion brevirostris. Copeia 1993: 425-434

> Morrissey JF, Gruber SH (1993b) Habitat selection by juvenile lemon sharks, Negaprion brevirostris. Environ Biol Fishes 38:311-319

Munday PL, Jones GP, Pratchett MS, Williams AJ (2008) Climate change and the future for coral reef fishes. Fish Fish 9:261-285

Musick JA, Colvocoresses JA, Foell EJ (1985) Seaonality and the distribution, availability and composition of fish assemblages in Chesapeake Bight. In: Yanez-Arancibia A (ed) Fish community ecology in estuaries and coastal lagoons: towards an ecosystem integration. Universidad Nacional Autónoma de México (UNAM) Press, Mexico City, p 451-474

Nam DH, Adams DH, Flewelling LJ, Basu N (2010) Neurochemical alterations in lemon shark (Negaprion brevirostris) brains in association with brevetoxin exposure. Aquat Toxicol 99:351-359

NMFS (National Marine Fisheries Service) (2009) Recovery plan for smalltooth sawfish (Pristis pectinata). Prepared by the Smalltooth Sawfish Recovery Team for the NMFS, Silver Spring, MD

Olsen AM (1954) The biology, migration and growth rate of the school shark, Galeorhinus australia (Macleay) (Carcharhanidae) in the southeastern Australian waters. Mar Freshw Res 5:353-410

> Ortega LA, Heupel MR, Van Beynen P, Motta PJ (2009) Movement patterns and water quality preferences of juvenile bull sharks (Carcharhinus leucas) in a Florida estuary. Environ Biol Fishes 84:361-373

> Ovenden JR, Morgan JAT, Street R, Tobin A, Simpfendorfer C, Macbeth W, Welch D (2011) Negligible evidence for regional genetic population structure for two shark species Rhizoprionodon acutus (Ruppell, 1837) and Sphyrna lewini (Griffith \& Smith, 1834) with contrasting biology. Mar Biol 158:1497-1509 
Parsons GR, Hoffmayer ER (2005) Seasonal changes in the distribution and relative abundance of the Atlantic sharpnose shark Rhizoprionodon terraenovae in the north central Gulf of Mexico. Copeia 2005:914-920

Robertson AI, Duke NC (1987) Mangroves as nursery sites: comparisons of the abundance and species composition of fish and crustaceans in mangroves and other nearshore habitats in tropical Australia. Mar Biol 96: 193-205

Ryer CH, Laurel BJ, Stoner AW (2010) Testing the shallow water refuge hypothesis in flatfish nurseries. Mar Ecol Prog Ser 415:275-282

Sala E, Ballesteros E, Starr RM (2001) Rapid decline of Nassau grouper spawning aggregations in Belize: fishery management and conservation needs. Fisheries 26: 23-30

Schindler DE, Hilborn R, Chasco B, Boatright CP, Quinn TP, Rogers LA, Webster MS (2010) Population diversity and the portfolio effect in an exploited species. Nature 465 : 609-612

Secor DH, Kerr LA, Cadrin SX (2009) Connectivity effects on productivity, stability, and persistence in a herring metapopulation model. ICES J Mar Sci 66:1726-1732

Sheaves M, Johnston R (2009) Ecological drivers of spatial variability among fish fauna of 21 tropical Australian estuaries. Mar Ecol Prog Ser 385:245-260

Simpfendorfer CA, Milward NE (1993) Utilisation of a tropical bay as a nursery area by sharks of the families Carcharhinidae and Sphyrnidae. Environ Biol Fishes 37 : 337-345

Simpfendorfer CA, Freitas GG, Wiley TR, Heupel MR (2005) Distribution and habitat partitioning of immature bull sharks (Carcharhinus leucas) in a southwest Florida estuary. Estuaries 28:78-85

Sims DW, Nash JP, Morritt D (2001) Movements and activity of male and female dogfish in a tidal sea lough: alternative behavioural strategies and apparent sexual segregation. Mar Biol 139:1165-1175

Editorial responsibility: Hans-Heinrich Janssen, Oldendorf/Luhe, Germany
Springer S (1967) Social organization of shark populations. In: Gilbert PW, Mathewson RW, Rall DP (eds) Sharks, skates and rays. Johns Hopkins Press, Baltimore, MD, p 149-174

Staples DJ (1979) Seasonal migration patterns of post-larval and juvenile banana prawns, Penaeus merguiensis de Man, in the major rivers of the Gulf of Carpentaria, Australia. Aust J Mar Freshw Res 30:143-157

Stevens JD, West GJ (1997) Investigation of school and gummy shark nursery areas in south eastern Australia. Report to the Fisheries Research \& Development Corporation, Project 93/061. CSIRO Marine Research, Hobart

Taylor EB (1991) A review of local adaptation in Salmonidae, with particular reference to Pacific and Atlantic salmon. Aquaculture 98:185-207

Taylor S, Sumpton W, Ham T (2011) Fine-scale spatial and seasonal partitioning among large sharks and other elasmobranchs in south-eastern Queensland, Australia. Mar Freshw Res 62:638-647

$>$ Tilman D (1996) Biodiversity: population versus ecosystem stability. Ecology 77:350-363

> Ubeda AJ, Simpfendorfer CA, Heupel MR (2009) Movements of bonnetheads, Sphyrna tiburo, as a response to salinity change in a Florida estuary. Environ Biol Fishes 84:293-303

Welch DJ, Ovenden J, Simpfendorfer C, Tobin A and others (2011) Stock structure of exploited shark species in north-eastern Australia. Report to the Fisheries Research \& Development Corporation, Project 2007/035. Fishing \& Fisheries Res Cent Tech Rep No. 12. James Cook University, Townsville

White WT, Potter IC (2004) Habitat partitioning among four elasmobranch species in nearshore, shallow waters of a subtropical embayment in Western Australia. Mar Biol 145:1023-1032

Williams SE, Bolitho EE, Fox S (2003) Climate change in Australian tropical rainforests: an impending environmental catastrophe. Proc R Soc Lond B 270:1887-1892

Submitted: November 30, 2011; Accepted: April 16, 2012

Proofs received from author(s): June 25, 2012 